\title{
ADIPOCYTOKINE CHANGES IN PATIENTS WITH STABLE ANGINA AND OBESITY*
}

\author{
T. N. Gabisoniia, P. P. Kravchun, R. V. Pashtiani \\ Kharkiv National Medical University, Kharkiv \\ tamri.gabisoniya@mail.ru
}

The most widespread among all cardiovascular diseases is the ischemic heart disease (IHD), which is found in $58 \%$ of patients. Despite significant progress in treatment, the prevalence of stable angina grows and reaches $20 \%$ among population $[1,2]$.

Obesity is an important risk factor of IHD development. Cardiovascular disorders in patients with obesity are found in the form of systemic atherosclerosis, myocardiodystrophy, arterial hypertension.

The results of the latest research in endocrinology have shown the presence of hormonal activity of adipose tissue and its indirect and direct impact on the body on the whole and on the cardiovascular system in particular [1]. Leptin, adiponectin, visfatin, tumor necrosis factor- $\alpha$, interleukin-6, interleukin- 8 etc. are attributed to the most important active substances which synthesize in adipocytes [3-5].

Active scientific research in pathogenic mechanisms of adipose tissue hormones biosynthesis and their role in development of obesity and cardiovascular diseases is performed. The level of adiponectin in patients with obesity is proved to be decreased. M. Kumada et al. have detected the decrease of plasma concentration of this protein in patients with IHD. They foresaw that hypoadiponectinemia could become a new significant risk factor of atherosclerosis and its complications [6].

Visfatin - adipokine, which is produced by visceral adipocytes, is being actively examined. Introduction of recombinant visfatin affects the insulin receptor in the same manner as insulin. The level of visfatin grows in proportion to the level of obesity $[7,8]$. According to the data provided by G. V. Kosygina the visfatin level of serum is statistically significantly higher in obesity than without it and is correlated with the indices of Total Cholesterol (TC) and cholesterol with low-density lipoproteins (LDL cholesterol) [8]. Maybe this molecule will become the key to the problem of lipid exchange, which is found in patients with obesity $[9,10]$.

${ }^{*}$ The research was carried out as part of investigation work at the Department of Internal Medicine № 2, Clinical Immunology and Allergology at Kharkiv National Medical University, Ministry of Health of Ukraine «Neurohumoral effects on the progression of chronic heart failure in patients with hypertension and coronary heart disease with renal dysfunction and anemic syndrome» (State registration number: 0111U001395).

Institution, which financed the research: Ministry of Health of Ukraine.

The authors assume responsibility for the published work.

The authors guarantee absence of competing interests and their own financial interest when carrying out the research and writing the article.

The manuscript was received by the editorial staff 15.12.2015. 
This sphere of medical research is challenging and up-to-date, since the acquired data is quite contradictory and requires further study with obtaining new reliable facts, which could become the basis for new diagnostic and therapeutic strategies in metabolic disorders in patients with cardiovascular pathology.
In this connection we have established the objective of research - to define the imbalance of adipocytokines (adiponectin and visfatin) in patients suffering from stable angina and concomitant obesity.

\section{MATERIALS AND METHODS}

We examined 110 patients with stable angina (Functional Classes II-III). All patients were divided into 2 groups: $1^{\text {st }}$ group - patients with stable angina with concomitant obesity $(n=80), 2^{\text {nd }}$ group - patients with stable angina without obesity $(n=30)$. The average age of the patients suffering from stable angina with concomitant obesity was $66.45 \pm 1.08$ years old, and of the 2 group $65.87 \pm 1.98 .66$ men $(60.95 \%)$ and 44 women $(39.05 \%)$ have been examined. The control group comprised 20 practically healthy people which one correspond by age and sex. The patients suffering from stable angina with concomitant acute or chronic inflammatory diseases, renal failure, oncological diseases and insulin dependent diabetes mellitus (IDDM) were not involved in the research.

All patients underwent comprehensive investigation in accordance with the order № 436 of Ministry of Health of Ukraine «Protocols on delivery of health care to the patients with IHD - stable angina».

Anthropometric measuring included measuring of height, body mass, waist circumference (WC) and hips circumference (HC). For characterizing obesity they used body mass index (BMI), which was determined with the help of the formula: $\mathrm{BMI}=$ body mass $(\mathrm{kg}) /$ height $\left(\mathrm{m}^{2}\right)$.

Detection of TC level and high-density lipoproteids (HDL) was realised with the help of peroxidase method using the set of reagents «Cholesterol Liquicolor» («Human» company, Germany) in blood serum, stabilized by heparin and EDTA. The method principle consists in the detection of TC after its enzymic hydrolysis and acidification. The index substance of $\mathrm{TC}$ is chilonimin, which is derived from hydrogen dioxode and 4-aminophenazone in the presence of phenol and peroxidase. Chylomicrons, very-low-density lipoproteins (VLDL), low-density lipoproteins (LDL) were deposited by adding phosphoromolybdic acid and magnesium chloride. After centrifugal separation in supernatant high-density lipoproteins (HDL) were left, the level of which was defined with the help of «Cholesterol Liquicolor» kit. The level of highdensity lipoproteins HDL $<0.9 \mathrm{mmol} / 1$ in men and $<1.0 \mathrm{mmol} / \mathrm{l}$ in women is the criterion for hypoalphacholesterolemia. The level of triglyceride (TG) was defined with the help of enzymic colorimetric method with the use of reagents kit «Triglycerides GPO» («Human», Germany). The method principle consisted in the fact that TG concentration was defined after enzymic hydrolysis under the action of lipase. As a result of the reaction the chilonimin indicator formed with hydrogen dioxide, 4-aminoantipyrine and 4-chlorophenol in catalytic impact of peroxidase. TG level $\geqslant 1.7 \mathrm{mmol} / \mathrm{l}$ in serum was considered to be a sign of hypertriglyceridemia. The atherogenic index (AI) was calculated according to the formula: $\mathrm{AI}=(\mathrm{TC}-\mathrm{HDL}): \mathrm{HDL}(\mathrm{mmol} / \mathrm{l})$; VLDL level $=\mathrm{TG}: 2.2 \times 0.45(\mathrm{mmol} / \mathrm{l}) ; \mathrm{LDL}$ level $(\mathrm{mmol} / \mathrm{l})=\mathrm{TC}-(\mathrm{VLDL}+\mathrm{HDL})$.

Adipokines level was defined by the immunoenzymometric methods on the immunoenzymometric analyzer «LabLine-90» (Austria). Adiponectin concentration was defined using the kit produced by «ElisaKit» company (USA). Visfatin concentration was defined using the kit produced by «VisfatinEIAKIT» company (USA).

The statistical processing of results was performed with the help of software package «Statistika» (StaSoftInc, USA). The values calculated: the average $(M)$, dispersion, stan- 
dard deviation, the median $(m)$, probability and level of significance $(p)$. They used the standard programme of correlation analysis with calculation of average arithmetic means:
$M \pm m, \sigma$, probability and level of accuracy $(p)$. Pearson correlation coefficient was used to evaluate the stage between samples $(r)$.

\section{RESULTS AND DISCUSSION}

According to the results of our investigation it was established that statistically in patients from the first group the level of visfatin significantly increase till $(29.6 \pm 2.0 \mathrm{ng} / \mathrm{ml})$ in comparison to the patients from the other group and control group $(27.6 \pm 1.7 \mathrm{ng} / \mathrm{ml}$; $19.3 \pm 1.3 \mathrm{ng} / \mathrm{ml}$ correspondingly). The attention is drawn to significant decrease of adiponectin in patients from the first group $(5.02 \pm 0.22 \mathrm{ng} / \mathrm{ml})$ in comparison to the second $(6.02 \pm 0.21 \mathrm{ng} / \mathrm{ml})$ and control group $(12.45 \pm 0.15 \mathrm{ng} / \mathrm{ml})$. This indicates that hypoadiponectinemia and hypervisfatinemia are associated with development of obesity in patients with stable angina (Table 1).

Given that the patients had different body weight, in our opinion, studying the imbalance between adipocytokins in accordance with BMI was very interesting. In this regard the patients were divided into following subgroups: $1^{\text {st }}$ subgroup - patients suffering from stable angina with increased body weight (IBW) $\left(\mathrm{BMI}=28.2 \pm 2.1 \mathrm{~kg} / \mathrm{m}^{2}\right)(n=16), 2^{\text {nd }}-\mathrm{pa}-$ tients suffering from stable angina with stage 1 concomitant obesity $\left(\mathrm{BMI}=30.1 \pm 1.0 \mathrm{~kg} / \mathrm{m}^{2}\right)$ $(n=34), 3^{\text {rd }}-$ patients suffering from stable angina with stage 2 concomitant obesity $\left(\mathrm{BMI}=35.7 \pm 1.9 \mathrm{~kg} / \mathrm{m}^{2}\right) \quad(n=16)$ and $4^{\text {th }}$ - patients with stable angina with stage 3 concomitant obesity $\left(\mathrm{BMI}=40.3 \pm 2.1 \mathrm{~kg} / \mathrm{m}^{2}\right)$ $(n=14)$.

We observed significant deterioration of adipokine exchange associated with weight gain in patients with stable angina, which was characterized by significant reduction of adiponectin level in patients from the first $(5.15 \pm 0.17 \mathrm{ng} / \mathrm{ml})$, the second $(5.11 \pm 0.22 \mathrm{ng} / \mathrm{ml})$, the third $(5.09 \pm 0.38 \mathrm{ng} / \mathrm{ml})$, the fourth $(4.74 \pm 0.28 \mathrm{ng} / \mathrm{ml})$ subgroups in comparison

T a b l e 1

Indicators of adipocytokine exchange in patients with stable angina in accordance with occurrence of obesity, $(M \pm m)$

\begin{tabular}{c|c|c|c|c}
\hline \multicolumn{1}{c|}{ Indicators } & $\begin{array}{c}\text { Stable angina }+ \\
\text { obesity }(\boldsymbol{n}=\mathbf{8 0})\end{array}$ & $\begin{array}{c}\text { Stable angina } \\
\text { without } \\
\text { concomitant } \\
\text { obesity }(\boldsymbol{n}=\mathbf{3 0})\end{array}$ & $\begin{array}{c}\text { Control group } \\
(\boldsymbol{n}=\mathbf{2 0})\end{array}$ & $\boldsymbol{p}$ \\
\hline Adiponectin, $\mathrm{ng} / \mathrm{ml}$ & $5.02 \pm 0.22$ & $6.02 \pm 0.21$ & $12.45 \pm 0.15$ & $\begin{array}{c}p_{1-2}<0.05 \\
p_{1-3}<0.05 \\
p_{2-3}<0.05\end{array}$ \\
\hline Visfatin, $\mathrm{ng} / \mathrm{ml}$ & $29.6 \pm 2.0$ & $27.6 \pm 1.7$ & $19.3 \pm 1.3$ & $\begin{array}{l}p_{1-2}<0.05 \\
p_{1-3}<0.05 \\
p_{2-3}<0.05\end{array}$ \\
\hline
\end{tabular}

$\mathrm{T}$ a b l e 2

Indices of adipocytokin exchange in accordance with the stage of obesity, $(M \pm m)$

\begin{tabular}{l|c|c|c|c|c}
\hline \multicolumn{1}{c|}{ Indices } & $\begin{array}{c}\text { IBW } \\
(\boldsymbol{n}=\mathbf{1 6})\end{array}$ & $\begin{array}{c}\text { Obesity 1 } \\
\text { stage }(\boldsymbol{n}=\mathbf{3 4})\end{array}$ & $\begin{array}{c}\text { Obesity 2 } \\
\text { stage }(\boldsymbol{n}=\mathbf{1 6})\end{array}$ & $\begin{array}{c}\text { Obesity 3 } \\
\text { stage }(\boldsymbol{n}=\mathbf{1 4})\end{array}$ & $\begin{array}{c}\text { Control group } \\
(\boldsymbol{n}=\mathbf{2 0})\end{array}$ \\
\hline Adiponectin, $\mathrm{ng} / \mathrm{ml}$ & $5.15 \pm 0.17^{*}$ & $5.11 \pm 0.22^{*}$ & $5.09 \pm 0.38^{*}$ & $4.74 \pm 0.28^{*}$ & $12.4 \pm 0.21^{*}$ \\
\hline Visfatin, $\mathrm{ng} / \mathrm{ml}$ & $25.1 \pm 2.1^{*}$ & $29.7 \pm 1.2^{*}$ & $30.0 \pm 2.0^{*}$ & $33.6 \pm 2.4^{*}$ & $19.3 \pm 1.7^{*}$ \\
\hline
\end{tabular}

$\mathrm{N}$ o t e. ${ }^{*} p<0.05$ - in the patient with stable angina depending of body weight and control group. 
to control group $(12.4 \pm 0.21 \mathrm{ng} / \mathrm{ml})$. Visfatin level, in its turn, reached $25.1 \mathrm{ng} / \mathrm{ml}$ in the first subgroup, $29.7 \mathrm{ng} / \mathrm{ml}$ in the second, $30 \mathrm{ng} / \mathrm{ml}$ in the third and $33.6 \mathrm{ng} / \mathrm{ml}$ in the fourth, which significantly exceeded the levels of this index in control group $(19.3 \pm 1.7 \mathrm{ng} / \mathrm{ml})$ (Table 2). Taking into account the above mentioned it is possible to say that a progression of atherosclerosis in patients with stable angina by way of exhaustion of antiatherogenic capabilities of adiponectin accompanied by activation of lipid disorders in patients with concomitant obesity with the help of visfatin.

The results of correlation analysis have shown that there are statistically significant ties practically between all indices of lipid and adipokine exchange. Thus direct correlation ties have been found in patients between visfatin and BMI $(r=0.46 ; p<0.05)$; between visfatin and AI $(r=0.58 ; p<0.05)$; VLDL and visfatin $(r=0.53 ; p<0.05)$; LDL and visfatin $(r=0.61 ; p<0.05) ; \mathrm{TG}$ and visfatin $(r=0.48 ; p<0.05)$, inverse correla- tion relationship was established between visfatin and $\operatorname{HDL}(r=-0.54 ; p<0.05)$, which shows that in patients suffering from stable angina with concomitant obesity together with growth of BMI a rise of visfatin level was observed, which caused atherogenic changes in lipid profile. Inverse correlation ties have also been established between adiponectin and BMI $(r=-0.44 ; p<0.05)$; adiponectin and HDL $(r=-0.56 ; p<0.05)$; adiponectin and VLDL $(r=-0.44 ; p<0.05)$; adiponectin and TG $(r=-0.41 ; p<0.05)$; adiponectin and AI $(r=-0.36 ; p<0.05)$ in its turn direct correlation ties have been observed between HDL and adiponectin $(r=0.38 ; p<0.05)$. Demonstrated rise of visfatin and reduction of adiponectin levels are associated with the increase of amount of visceral fat and severity of obesity. The data we've received is consistent with the general notion about atherogenic characteristics of visfatin and its ability to aggravate metabolic disorders, including lipid exchange.

\section{CONCLUSIONS}

1. According to the results of our study among the patients with stable angina with concomitant obesity the level of adiponectin is $17 \%$ lower and visfatin level is $9.3 \%$ higher in comparison to patients without obesity.

2. Adipokine exchange dysfunction contributes to development of atheroscle- rosis in patients suffering from stable angina with concomitant obesity through exhaustion of antiatherogenic capabilities of adiponectine together with activation of lipid disorders with the help of visfatin, which is confirmed by the detected correlation ties.

\section{PROSPECTS FOR FURTHER RESEARCH}

A more detailed study of the role of other hormones of adipose tissue in the progression of atherosclerosis will interesting in patient with concominant obesity.

\section{REFERENCES}

1. Gorbas IM. Zdoroviya Ukraini 2007; 21(1):62-63.

2. Kravchun PG, Shelest OM. Medicina Siogodni I Zavrta 2012: 1:11.

3. Vizir VA, Berezin AE. Ukr Med Chasopis 2010; 2:2336 .

4. Kovaliova OM, Asheulova TV, Ambrosova TV. Praktichna Angiologiya 2009; 9-10:12-16.

5. Colberg B. Prob Endocr Patologii 2009; 55(1):38-44.
6. Kumada M, Ki'hara S, Sumitsuji S. Arterioscler Thromb Vasc Biol 2003; 23: 85-89.

7. Babak OI, Klimenko NN. Ukr Ter J 2010; 2:94-100.

8. Kosigina AV. Gormoni jirovoi tkani - adiponectim I visvatin pri ojirenii, Moskva, 2011: 20 p.

9. Anghel SI, WahliW. Research 2007; 17:486-511.

10. Fonseca Alaniz MH, Takada MI, Cardoso AlonsoVale J, Lima FB. J Pediatr (Rio J) 2007; 83:S192S203. 


\title{
ЗМІНИ АДИПОКІНОВОГО ПРОФІЛЮ У ХВОРИХ НА СТАБІЛЬНУ СТЕНОКАРДІЮ ТА ОЖИРІННЯ
}

\author{
Габісонія Т. Н., Кравчун П. П., Паштіані Р. В. \\ Харківсъкий націоналъний медичний університет, м. Харків \\ tamri.gabisoniya@mail.ru
}

\begin{abstract}
Стаття присвячена вивченню впливу гормонів жирової тканини на розвиток атеросклерозу у хворих на стабільну стенокардію з супутнім ожирінням. Встановлено, що дисфункція адипокінового обміну сприяє розвитку гіперліпідемії та як наслідок цього прогресуванню атеросклерозу у хворих на стабільну стенокардію та ожиріння. За результатами нашого дослідження у хворих на стабільну стенокардію та ожиріння, виялено зниження рівня адипонектину на $17 \%$ та підвищення рівня вісфатину на 9,3\% у порівнянні з хворими без ожиріння.
\end{abstract}

К л ю ч о в і с л о в а: адипонектин, вісфатин, стабільна стенокардія, ожиріння, ліпідний профіль.

\section{ИЗМЕНЕНИЯ АДИПОКИНОВОГО ПРОФИЛЯ У БОЛЬНЫХ СТАБИЛЬНОЙ СТЕНОКАРДИЕЙ И ОЖИИЕНИЯ}

\author{
Габисония Т. Н., Кравчун П. П., Паштиани Р. В.
}

Харъковский националънъй медицинский университет, г. Харъков

tamri.gabisoniya@mail.ru

Статья посвящена изучению влияния гормонов жировой ткани на развитие атеросклероза у больных со стабильной стенокардией и сопутствующим ожирением. Установлено, что дисфункция адипокинового обмена способствует развитию гиперлипидемии и как следствие этого прогрессированию атеросклероза у больных со стабильной стенокардией и ожирением. По результатам нашего исследования у больных стабильной стенокардией и ожирения, выялено снижение уровня адипонектина на $17 \%$ и повышение уровня висфатину на $9,3 \%$ по сравнению с больными без ожирения.

К л ю ч е в ы е с л о в а: адипонектин, висфатин, стабильная стенокардия, ожирение, липидный профиль.

\section{ADIPOCYTOKINE CHANGES IN PATIENTS WITH STABLE ANGINA AND OBESITY}

T. N. Gabisoniia, P.P. Kravchun, R. V. Pashtiani

Kharkiv National Medical University, Kharkiv

tamri.gabisoniya@mail.ru

The article studied the effects of adipokines in the development of atherosclerosis in patients with stable angina and concomitant obesity. Established that dysfunction adipokinocytes exchange promotes hyperlipidemia and consequently the progression of atherosclerosis in patients with stable angina and obesity. According to the results of our study among the patients with stable angina with concomitant obesity the level of adiponectin is $17 \%$ lower and visfatin level is $9.3 \%$ higher in comparison to patients without obesity.

K e y w o r d s: adiponectin, visfatin, stable angina, obesity, lipid profile. 